\title{
KAJIAN WACANA DAMPAK PENGGUNAAN GADGET (GAWAI) TERHADAP KEMAMPUAN SOSIAL EMOSIONAL PADA ANAK USIA DINI
}

\author{
Intan Nur Laily \\ Institut Keguruan dan Ilmu Pendidikan PGRI Jember \\ Intannurlaily354@gmail.com \\ Ratnasari Dwi Ade Chandra \\ Institut Keguruan dan Ilmu Pendidikan PGRI Jember \\ ratnasaridwi082@mail.com
}

\begin{abstract}
Abstrak
Penelitian ini dilatar belakangi adanya penggunaan gadget pada anak usia dini yang memiliki dampak positif dan negatif, salah satunya dalam kemampuan sosial emosional anak. kebanyakan orang tua kurang memahami dampak penggunaan gadget pada anak, adanya pemberian gadget pada anak agar tidak mengganggu kesibukan orangtua, mengenalkan teknologi sejak dini dan memperbanyak teman di dunia maya yang mana hal tersebut akan mempengaruhi kemampuan sosial emosional anak. faktanya, kemampuan sosial emosional pada anak sangat perlu dikembangkan sejak dini agar anak tumbuh dan berkembang sesuai harapan. Oleh karena itu, dibutuhkan penelitian tentang dampak penggunaan gadget terhadap kemampuan sosial emosional pada anak usia dini. Penelitian ini termasuk penelitian kepustakaan dengan pendekatan penelitian kualitatif. Sumber data yang diambil adalah dari data kepustakaan berupa buku-buku dan jurnal-jurnal penelitian sesuai dengan kajian yang akan diteliti. Hasil penelitian menjelaskan bahwa penggunaan gadget pada anak usia dini memiliki dampak terhadap kemampuan sosial emosional anak.
\end{abstract}

Kata Kunci: Gadget, Kemampuan Sosial Emosional, Anak Usia Dini

\begin{abstract}
This research is motivated by the use of gadgets in early childhood which has positive and negative impacts, one of which is in children's social emotional abilities. Most parents do not understand the impact of using gadgets on children, providing gadgets to children so as not to interfere with parents' activities, introducing technology from an early age and making friends in cyberspace which will affect the child's social emotional ability in fact, social emotional abilities in children really need to be developed from an early age so that children grow and develop as expected. Therefore, research is needed on the impact of gadget use on socio-emotional abilities in early childhood. This research includes literature research with a qualitative research approach. Sources of data taken are from library data in the form of books and research journals in accordance with the study to be studied. The results of the study explain that the use of gadgets in early childhood has an impact on children's social emotional abilities.
\end{abstract}

Keywords: Gadgets, Social Emotional Ability, Early Childhood 


\begin{tabular}{|l|c|c|}
\hline \multicolumn{3}{|c|}{ Jurnal Warna : Jurnal Pendidikan Dan Pembelajaran Anak Usia dini. } \\
Maret 2021 . Vol 06. No. 01
\end{tabular}

\section{PENDAHULUAN}

Teknologi saat ini semakin pesat dan canggih. Hampir setiap hari, kapan saja dan dimana saja manusia menggunakan teknologi. Gadget (Gawai) adalah salah satu alat teknologi yang banyak diminati dari berbagai kalangan, mulai dari kalangan tua, muda sampai anak-anak. Dalam gadget (gawai), terdapat fitur-fitur yang menarik, misalkan dalam hal bersosialita ada aplikasi yang bernama whatsApp, twitter, instagram, facebook dan lain-lain. Dimana dengan adanya aplikasi tersebut pengguna dapat saling mengirim pesan teks, suara bahkan dapat saling melihat satu sama lain atau biasa disebut dengan videocall.

Pada hakikatnya pendidikan ialah wadah dalam mengembangkan kemampuan peserta didik. Seorang pendidik mempunyai peran yang sangat penting dalam upaya meningkatkan kemampuan peserta didik sehingga pendidik dapat memahami perkembangan peserta didiknya. Anak usia dini adalah peserta didik paling awal yang memiliki tingkat pencapaian perkembangan luar biasa, yang mana mereka paling awal dalam mempelajari konsep kehidupan. Anak usia dini merupakan individu dalam proses perkembangan untuk kehidupan selanjutnya. Masa ini juga terjadi proses perkembangan dan pertumbuhan dari berbagai aspek, termasuk aspek sosial emosional.

Menurut Mayar (2013), menjelaskan bahwa perkembangan sosial anak ditandai dengan bagaimana anak berinteraksi dengan teman sebaya, dan orang-orang disekitarnya supaya dapat menyesuaikan diri dengan baik sesuai dengan apa yang diharapkan oleh bangsa dan negara. Perkembangan sosial tidak terlepas dari peran keluarga khususnya orangtua karena anak belajar bagaimana bersosialisasi dari orangtua. Relasi awal dari keluarga adalah pondasi tercapainya hubungan dengan teman sebayanya. Apabila dirumah anak kurang berinteraksi dengan keluarganya kemungkinan saat diluar rumah anak akan kesulitan berinteraksi dengan teman sebayanya (Soetjiningsih, 2012:213).

Santrock (2007) dalam bukunya yang berjudul Perkembangan Anak, menjelaskan bahwa pola perkembangan manusia dihasilkan oleh hubungan dari beberapa proses kognitif, biologis dan sosial emosi. Santrock menyatakan bahwa proses biologis menghasilkan perubahan pada tubuh seseorang. Termasuk gen diwariskan orangtua, pertambahan tinggi dan berat badan serta perkembangan otak mencerminkan peran proses biologis dalam perkembangan.

Proses sosial emosi melibatkan perubahan dalam hubungan dengan orang lain, yaitu perubahan emosi dan 


\begin{tabular}{|c|c|c|}
\hline \multicolumn{3}{|c|}{ Jurnal Warna : Jurnal Pendidikan Dan Pembelajaran Anak Usia dini. } \\
Maret 2021. Vol 06. No. 01 \\
\hline Received: September 2020 & Accepted: Januari 2021 & Published: Maret 2021 \\
\hline & Article DOI: 10.24903/jw.v4i2.679 \\
\hline
\end{tabular}

kepribadian. Santrock memberi contoh bahwa bayi tersenyum karena merasakan sentuhan ibunya, hal tersebut adalah respon yang sangat sederhana yang memerlukan proses biologis dan kognitif dan proses sosial emosi positif dan senyuman membantu menghubungkan bayi dengan orang disekitarnya.

Perlu diketahui bahwa pada periode perkembangan anak sangat sensitif saat anak berusia 1-5 tahun, karena pada masa ini anak mengalami masa golden age atau masa keemasan. Pada masa ini seluruh aspek perkembangan kecerdasan, misalnya kecerdasan spiritual, intelektual dan emosi mengalami perkembangan yang sangat pesat sehingga akan menentukan perkembangan selanjutnya. Ketika anak berada pada masa keemasan semua informasi akan terserap dengan cepat. Anak-anak menjadi peniru yang handal, lebih pintar bahkan lebih cerdas dari apa yang kita lihat. Hal tersebut akan menjadi dasar terbentuknya kepribadian, karakter dan kemampuan kognitifnya.

Penggunaan gadget pada anak prasekolah juga dapat digunakan sebagai media belajar untuk menstimulasi perkembangan anak sedangkan menurut Vitrianingsih Khadijah dan Ceria (2018), menjelaskan bahwa penggunaan gadget anak untuk bermain games, puzzel dan menonton video yang mana hal tersebut berdampak baik dalam perkembangan anak. Menurut Sundus (2018) dan Yenny (2017) mengungkapkan bahwa beberapa konten tertentu dapat mengembangkan kemampuan kognitif dan motorik halus anak. Menurut Imron (2017), menjelaskan bahwa penggunaan gadget pada anak usia dini dengan intensitas tinggi berhubungan negatif dengan perkembangan sosial emosional anak.

Faktanya, selain gadget memiliki dampak negatif ada juga dampak positifnya diantaranya dalam kognitif anak mampu mengolah strategi permainan, mengatur kecepatan bermain dan membantu meningkatkan kemampuan otak kanan selama orangtua mampu mengawasi anak dalam bermain gadget. Namun, dalam penggunaan gadget harus diatur seperti memberi jarak antara mata dengan gadget, posisi duduk yang benar karena radiasi yang dipancarkan dapat merusak jaringan syaraf otak anak apabila anak terlalu sering menggunakan gadget.

Penggunaan gadget zaman ini bukan hanya digunakan oleh orang-orang yang memiliki kepentingan saja namun juga sudah digunakan oleh anak usia dini. Dalam penggunaannya juga berbeda dilihat dari segi waktu dan fungsinya. Anak usia dini adalah anak yang sedang dalam proses perkembangan dan pertumbuhan. Pada masa tersebut anak akan mengalami perkembangan yang luar biasa terletak pada 6 (enam) aspek perkembangan seperti 


\begin{tabular}{|c|c|c|}
\hline \multicolumn{3}{|c|}{ Jurnal Warna: Jurnal Pendidikan Dan Pembelajaran Anak Usia dini. } \\
Maret 2021. Vol 06. No. 01 \\
\hline Received: September 2020 & Accepted: Januari 2021 & Published: Maret 2021 \\
\hline & Article DOI: 10.24903/jw.v4i2.679 \\
\hline
\end{tabular}

kognitif, bahasa, fisik motorik, seni, nilai dan moral agama serta sosial emosional.

Sejalan dengan pernyataan diatas, pentingnya dalam mengembangkan kemampuan sosial emosional sejak usia dini untuk dapat mengembangkan kemampuan sosial emosional anak dimasa mendatang. Dalam penggunaan gadget anak akan terlihat asyik dengan dunianya, kurang peka dengan lingkungan, serta akan mengalami perubahan emosi. Hal tersebut juga akan menghambat perkembangan dan pertumbuhan anak. Maka berdasarkan permasalahan tersebut dibutuhkan penelitian tentang dampak penggunaan gadget terhadap kemampuan sosial emosional pada anak usia dini. Penelitian ini diharapkan dapat dijadikan kajian untuk mengetahui dampak penggunaan gadget (gawai) terhadap kemampuan sosial emosional pada anak usia dini. Sehingga anak tumbuh dan berkembang sesuai usianya, dapat memanfaatkan teknologi dengan baik dan menghindari anak dari dampak negatif penggunaan gadget.

\section{METODE PENELITIAN}

\section{Jenis dan Pendekatan Penelitian}

Pendekatan penelitian yang dilakukan peneliti menggunakan penelitian kualitatif. Penelitian kualitatif ini dilakukan dengan cara mencari data dan informasi sebanyak-banyaknya yang diperoleh dari sumber-sumber baik itu dari jurnal, skripsi, buku, majalah dan lain-lain. Jenis penelitian ini termasuk penelitian kepustakaan (Library Research), yang mana bisa disebut studi literasi karena sumber datanya mengarah pada pustaka.

Menurut Mestika Zed, maka ada 4 (empat) ciri utama dalam penelitian kepustakaan yaitu ; 1)Peneliti berhadapan langsung dengan teks atau data angka dan bukan pengetahuan langsung dari lapangan berupa kejadian, benda atau orang; 2) Data pustaka bersifat siap pakai ini menandakan bahwa peneliti tidak pergi kemana-mana kecuali hanya berhadapan langsung dengan bahan sumber yang telah sedia di perpustakaan; 3) Pada umumnya data pustaka merupakan sumber sekunder. Itu artinya peneliti memperoleh data dari tangan kedua bukan dari tangan pertama; 4) Kondisi data pustaka tidak dibatasi oleh ruang dan waktu (Mestika Zed, 2004:4-5).

\section{Sumber Data}

Peneliti mengambil sumber data dari bahan-bahan pustaka seperti jurnal, skripsi dan buku. Adapun sumber-sumber data tersebut adalah ; 1) Buku karya Novi Mulyani, M.Pd.I dengan judul asli“Dasardasar Pendidikan Anak Usia Dini”. Judul buku tersebut adalah judul buku ke-4 penulis dari beberapa buku yang ditulis penulis. Buku ini diterbitkan oleh kalimedia di Yogyakarta tahun 2016. Hal 99-113; 2) Buku karya Ali Nugraha dan Yeni Rachmawati dengan judul buku "Metode Pengembangan Sosial Emosional". Buku ini diterbitkan oleh Universitas Terbuka. Hal 1.3-1.20; 3) Jurnal Penelitian dari Femmi 


\begin{tabular}{|c|c|c|}
\hline \multicolumn{3}{|c|}{ Jurnal Warna : Jurnal Pendidikan Dan Pembelajaran Anak Usia dini. } \\
Maret 2021. Vol 06. No. 01 \\
\hline Received: September 2020 & Accepted: Januari 2021 & Published: Maret 2021 \\
\hline & Article DOI: 10.24903/jw.v4i2.679 \\
\hline
\end{tabular}

Nurmalitasari yang berjudul "Perkembangan Sosial Emosi pada Anak Usia Prasekolah”. Dalam Buletin Psikologi Volume 23, No. 2, Desember 2015:103-111. Fakultas Psikologi Universitas Gadjah Mada, ISSN: 0854-7108; 4) Jurnal Penelitian dari Mira Rahmawati dan Melly Latifah yang berjudul "Penggunaan Gawai, Interaksi Ibu-Anak, dan Perkembangan Sosial-Emosional Anak Prasekolah". Dalam Jur. Ilm. Kel. \& Kons., Januari 2020, p: 75-86 Vol. 13, No 1. ISSN: 2502-3594.; 5) Jurnal Penelitian dari Intan Diyah Retno Palupi dalam Jurnal Edukasi NonFormal dengan judul "Pengaruh Media Sosial pada Perkembangan Kecerdasan Anak Usia Dini”. E-ISSN: 27152634; 6) Jurnal penelitian dari Putri Hana Pebriana yang berjudul“'Analisis Penggunaan Gadget Terhadap Interaksi Sosial Pada Anak usia Dini”. Dalam Jurnal Obsesi: Jurnal Pendidikan Anak Usia Dini Volume 1 Issue 1 (2017) pages 1-11; 7) Jurnal penelitian dari Listia Dwi Febriani dan Afroh Fauziah yang berjudul "Pengaruh Intensitas Penggunaan Gadget Terhadap Sosial Emosional Anak Usia Pra Sekolah di TK Yogyakarta”. Vol. 5 No. 1 Tahun 2020. ISSN: 2503-2461; 8) Jurnal Penelitian dari Munisa yang berjudul "Pengaruh Penggunaan Gadget Terhadap Interaksi Sosial Anak Usia Dini di TK Panca Budi Medan”. Vol. 13 No 1 Juni 2020. ISSN: 1979-5408.

\section{Prosedur Penelitian}

Adapun langkah-langkah yang peneliti gunakan adalah Studi Pustaka merupakan Dalam semua jenis penelitian menggunakan studi pustaka khususnya penelitian historis, yang mana data-data diperoleh dari kajian pustaka. Dan peneliti tidak hanya sekedar membaca dan mencatat literatur atau sumber-sumber yang lain. Namun, apa yang dimaksud riset pustaka dijelaskan oleh Mestika Zed adalah serangkaian kegiatan yang berkenaan dengan cara pengumpulan data pustaka., membaca dan mencatat dan mengolah bahan penelitian. Sedangkan berbeda dari pendapat Kartini Kartono, studi pustaka bertujuan mengumpulkan data dan informasi dengan berbagai macam materi yang terdapat dalam perpustakaan.

\section{Teknik pengumpulan data}

Adapun Teknik pengumpulan data menggunakan Dokumentasi adalah Pengumpulan data pada teknik ini dilakukan dengan penelusuran data pada buku-buku atau dokumen yang telah dijadikan sumber data. Teknik juga diartikan sebagai proses pembuktian yang didasarkan atas jenis sumber apapun baik barupa gambar, lisan, ataupun tulisan.

\section{Analisis Data}

Analisis Data terdiri dari ; 1) Menetapkan tema dan kata kunci yang akan dicari dalam dokumen yang akan diteliti serta dikaji. Tema dan kata kunci yang dimaksud adalah informasi yang berkaitan dengan dampak penggunaan gadget terhadap kemampuan sosial emosional pada anak usia dini; 2) Dapat memberi makna pada tema dan kata kunci yang akan dicari. Caranya adalah dengan mempelajari dan menelusuri isi makna yang ada pada tema dan kata kunci. Hal ini 


\begin{tabular}{|l|c|c|}
\hline \multicolumn{3}{|c|}{ Jurnal Warna : Jurnal Pendidikan Dan Pembelajaran Anak Usia dini. } \\
Maret 2021 . Vol 06. No. 01
\end{tabular}

bertujuan untuk memperjelas keseluruhan informasi dan pengertian yang akan disampaikan, baik melalui statement atau pernyataan yang terdapat dalam buku, jurnal, skripsi, dan web (internet) tersebut; 3) Melakukan interpretasi internal, maksudnya adalah seluruh informasi yang diperoleh dan telah ditetapkan sebagai data masih harus diuji keabsahannya secara internal melalui sumber yang sama. Pengujian keabsahan bertujuan untuk mengetahui adakah informasi yang bertentangan atau tidak dengan informasi lain data sumber data yang sama.

\section{Pengecekan Keabsahan Data}

Pengecekan keabsahan data dalam sebuah penelitian diperlukan guna membuktikan bahwa data yang diperoleh dapat dipertanggung jawabkan kebenarannya. Dalam teknik pengumpulan data, triangulasi dapat diartikan sebagai teknik pengumpulan data pada sumber data yang telah ada. Triangulasi yang digunakan peneliti adalah triangulasi sumber yaitu dengan menggali kebenaran informasi tertentu melalui berbagai metode dan sumber perolehan data. Sumber yang dimaksud adalah buku, jurnal, dan internet. Dengan menggunakan metode tersebut akan dihasilkan bukti atau data yang berbeda tujuannya dapat memberikan pandangan yang berbeda dengan fenomena yang diteliti. Pandangan tersebut akan memunculkan luasnya pengetahuan untuk memdapatkan kebenaran handal.

\section{Tahap-tahap Penelitian Data}

1. Menyiapkan alat perlengkapan

Tahap ini, peneliti menyiapkan segala sesuatu yang dibutuhkan misalkan pensil, pena dan alat untuk mencatat sumber buku sebagai bahan referensi

2. Menyusun bibliografi kerja

Hal yang harus peneliti lakukan selanjutnya adalah mulai menyusun bibliografi kerja yaitu catatan mengenai bahan sumber penting yang akan digunakan dalam kepentingan penelitian.

3. Mengatur waktu

Pengaturan waktu harus dilakukan untuk menghindari waktu yang terbuang sia-sia. Waktu penelitian harus diatur dari kapan dimulai sampai penelitian selesai.

4. Membaca dan membuat catatan penelitian

Pada tahap terakhir ini, peneliti harus membaca bahanbahan dan membuat catatan penelitian yang berguna untuk kelengkapan bahan yang diperlukan dalam penelitian.

\section{HASIL PENELITIAN}

Berdasarkan hasil penelitian dari Intan Dyah Retno Palupi dalam Jurnal yang berjudul "Pengaruh Media Sosial pada 


\begin{tabular}{|c|c|c|}
\hline \multicolumn{3}{|c|}{ Jurnal Warna : Jurnal Pendidikan Dan Pembelajaran Anak Usia dini. } \\
Maret 2021. Vol 06. No. 01 \\
\hline Received: September 2020 & Accepted: Januari 2021 & Published: Maret 2021 \\
\hline & Article DOI: 10.24903/jw.v4i2.679 \\
\hline
\end{tabular}

Perkembangan Kecerdasan Anak Usia

Dini" E-ISSN: 2715-2634 menyatakan bahwa pemberian media sosial berupa Youtube yang berbentuk video adalah salah satu langkah yang tepat dalam menstimulasi anak usia dini. Selain itu, Youtube juga dapat mempengaruhi perkembangan kecerdasan emosional (EQ), kecerdasan intelektual (IQ), kecerdasan spiritual (SQ) serta sosial anak. Berdasarkan hasil penelitian pengaruh kecerdasan emosional adalah faktor kondisi kebiasaan dan lingkungan. Pada faktor kebiasaan, biasanya anak diberikan tontonan di Youtube ini akan menumbuhkan rasa ingin tahu anak sehingga anak akan bertanya mengenai apa yang ia lihat.

Dalam kecerdasan intelektual (IQ), Youtube juga dapat mempengaruhi tingkat ketertarikan anak terhadap belajar menurun dan berpengaruh pada potensi belajar anak. Selain itu terdapat dampak positif yaitu anak dapat menguasai beberapa kata, angka dalam bahasa inggris, warna-warna selain itu anak juga mulai hafal lagu-lagu tradisional. Perkembangan imajinasi yang terjadi anak akan mulai berkhayal menganggap bahwa menggambar orang diibaratkan keluarga sendiri, memulai sebuah obrolan dengan benda mati seperti boneka yang seolah-olah memiliki perasaan dan hidup.
Kecerdasan Spiritual (SQ) yang dipengaruhi penggunaan Youtube pada anak dapat membantu melaksanakan peribadahannya. Hal tersebut juga sangat dipengaruhi peran orang tua dalam mengontrol dan membimbing anak dalam menggunakan aplikasi Youtube. Pengaruh kecerdasan ini cukup baik dan mengurangi dampak negatif yang terjadi yang mana dapat merubah kebiasaan anak. keluarga juga diharapkan menanamkan rasa takut tehadap Tuhan Yang Maha Esa. Karena apa yang diperbuat setiap manusia, Tuhan selalu mengawasi.

Berdasarkan hasil penelitian dalam Jurnal penelitian dari Putri Hana Pebriana yang berjudul“Analisis Penggunaan Gadget Terhadap Interaksi Sosial Pada Anak usia Dini”. Dalam Jurnal Obsesi: Jurnal Pendidikan Anak Usia Dini Volume 1 Issue 1 (2017) pages 1-11, yang dilakukan oleh Nurrachmawati (2014), menjelaskan bahwa para orangtua yang memberikan gadget kepada anaknya adalah berdasarkan keinginan anak dan agar anak tidak bosan atau sekedar mengenalkan teknologi lebih dini. Para orangtua mempunyai anggapan bahwa dengan memberikan gadget pada anak usia dini bertujuan untuk memperluas jaringan persahabatan mereka sehingga akan mudah dan cepat bergabung ke sosial media yang tersedia. Menurut penelitian yang dilakukan Widiawati dan Sugiman (2014), 


\begin{tabular}{|c|c|c|}
\hline \multicolumn{3}{|c|}{ Jurnal Warna : Jurnal Pendidikan Dan Pembelajaran Anak Usia dini. } \\
Maret 2021. Vol 06. No. 01 \\
\hline Received: September 2020 & Accepted: Januari 2021 & Published: Maret 2021 \\
\hline & Article DOI: 10.24903/jw.v4i2.679 \\
\hline
\end{tabular}

biasanya orangtua menyediakan gadget terhadap anaknya yang masih dini untuk mengalihkan anak supaya tidak mengganggu pekerjaan orangtuanya.

Penelitian yang dilakukan oleh Novitasari (2016), penggunaan gadget pada anak usia dini menjelaskan bahwa pemakaian gadget lebih menyenangkan dibandingkan bermain dengan teman sebayanya. Hal ini disebabkan oleh berbagai aplikasi permainan yang terdapat pada gadget anak, yang tentunya lebih menarik perhatian anak dibandingkan dengan permainan-permainan yang terdapat di lingkungan sekitarnya. Disaat anak-anak bermain gadget, mereka akan cenderung diam di depan gadgetnya tanpa mempedulikan lingkungan sekitarnya dan secara tidak sadar, anak-anak mengalami ketergantungan dalam menggunakan gadget.

Gadget adalah alat teknologi yang tidak asing lagi bagi anak zaman sekarang, apalagi dalam proses pembelajaran saat ini anak sekolah belajar secara online (daring) sehingga anak akan sering browsing tugas sekolahnya. Oleh karena itu, manfaat internet ialah kita dapat menambah wawasan pengetahuan. Selain untuk browsing ilmu internet juga dapat mengasah kreativitas anak. Hal ini juga disampaikan oleh Ameliola dan Hanggara (2013) bahwa penggunaan gadget pada anak usia dini adalah mengasah kecerdasan dan kreativitas anak dalam gadget terdapat aplikasi belajar membaca, menulis huruf dan mewarnai.

Hasil penelitian dalam Jurnal penelitian dari Listia Dwi Febriani dan Afroh Fauziah yang berjudul "Pengaruh Intensitas Penggunaan Gadget Terhadap Sosial Emosional Anak Usia Pra Sekolah di TK Yogyakarta”. Vol. 5 No. 1 Tahun 2020. ISSN: 2503-2461 menunjukkan bahwa rata-rata anak menghabiskan waktunya dengan bermain gadget selama 1-2 jam per hari. Berdasarkan informasi dari orangtua, anak mulai sibuk dengan aktifitas belajar disekolah, ketika pulang dilanjutkan bermain dengan teman sebaya dan pada sore hari untuk istirahat serta berangkat mengaji di TPQ. Menurut American Academy of Pediatric (AAP), dalam durasi penggunaan gadget bagi anak tidak boleh lebih dari 1-2 jam per hari (American Academy of Pediatrics Committee of Public Education, 2001).

Berdasarkan penelitian dalam Jurnal Penelitian dari Munisa yang berjudul "Pengaruh Penggunaan Gadget Terhadap Interaksi Sosial Anak Usia Dini di TK Panca Budi Medan”. Vol. 13 No 1 Juni 2020. ISSN: 1979-5408, Dalam penggunaan gadget terhadap anak usia dini, bergantung pada orangtua yang mengizinkannya. Anak bermain gadget sesuai dengan aturan yang orangtua buat. Berdasarkan hasil wawancara dengan para 


\begin{tabular}{|c|c|c|}
\hline \multicolumn{3}{|c|}{ Jurnal Warna : Jurnal Pendidikan Dan Pembelajaran Anak Usia dini. } \\
Maret 2021. Vol 06. No. 01 \\
\hline Received: September 2020 & Accepted: Januari 2021 & Published: Maret 2021 \\
\hline & Article DOI: 10.24903/jw.v4i2.679 \\
\hline
\end{tabular}

orangtua, dihasilkan bahwa $75 \%$ orangtua menggunakan handphone di depan anak mereka, yang mana hal tersebut mengakibatkan anak-anak penasaran dan ingin menggunakan alat teknologi tersebut. Ada dua tipe orangtua dalam memberikan gadget pada anak usia dini yaitu orangtua hanya memberikan gadget pada hari tertentu saja dan ada yang setiap hari memberikan dan memperbolehkan anak bermain gadget. Hal ini tidak terlepas dari berbagai alasan orangtua hanya sekedar untuk menambah wawasan, sebagai hiburan dan sarana edukasi anak.

Menurut pendapat para pakar pendidikan dalam Maulida, Hidayahti (2013), "Seharusnya pemahaman tentang fungsi dan cara menggunakan gadget dikenalkan pada saat anak usia enam tahun, dikarenakan pada usia tersebut perkembangan otak anak mulai meningkat sekitar 95\% dari otak orang dewasa. Sebab, jika gadget dikenalkan di bawah usia enam tahun, maka anak akan lebih banyak bermain karena anak tertarik dengan suara yang beragam dan gambar (visual) yang terdapat pada gadget".

Pengenalan tentang gadget pada anak usia dini memang tidak salah, namun orangtua diharapkan mampu ikut serta dalam mengawasi anaknya saat menggunakan gadget. Tujuanya menghindari hal-hal yang tidak diinginkan. Oleh karena itu, diharapkan adanya pembatasan waktu penggunaan gadget pada anak, serta orangtua lebih mengenalkan anak pada kehidupan sekitarnya. Menurut Journal of Pediatric Health Care yang berjudul The Impact of Technology Dependence on Children and Their Families menjelaskan bahwa anakanak zaman sekarang lebih bergantung pada teknologi begitu juga dengan keluarga mereka, yang mana teknologi tersebut memiliki dampak terhambatnya komunikasi dalam keluarga dan aktivitas sehari-hari menjadi kesulitan (Mesman, dkk 2013: 456).

\section{KESIMPULAN}

Dampak penggunaan gadget terhadap kemampuan sosial emosional anak usia ini memiliki dampak positif dan negatif. Untuk dampak positifnya yaitu anak dapat mengasah kreativitasnya, mengembangkan kemampuan kognitif dengan melihat video dari aplikasi Youtube dan selain itu juga dapat menumbuhkan rasa ingin tahu mengenai apa yang dilihat. Begitu juga anak dapat mulai menguasai lagu-lagu tradisional, mengenal warna serta mengembangkan imajinasi anak yang menganggap gambar yang anak lihat seolah-olah hidup dan memiliki perasaan. Untuk dampak negatifnya anak akan cenderung bermain sendiri, kurang peka dengan lingkungan sehingga anak menjadi pribadi individualis. Penggunaan gadget 


\begin{tabular}{|c|c|c|}
\hline \multicolumn{3}{|c|}{ Jurnal Warna : Jurnal Pendidikan Dan Pembelajaran Anak Usia dini. } \\
Maret 2021. Vol 06. No. 01
\end{tabular}

yang terlalu lama juga akan berpengaruh pada kejiwaannya misalnya anak akan lebih agresif, sensitif dan mudah marah.

$$
\text { Berdasarkan hasil penelitian, }
$$
penggunaan gadget pada anak usia dini mayoritas berdampak negatif daripada dampak positifnya. Hal tersebut juga tergantung bagaimana pengawasan dan bimbingan dari orangtua, karena dalam masa anak-anak sangat penting dalam mengembangkan aspek perkembangan anak sesuai tahapan usianya. Dengan orangtua dapat mencegah dampak negatif penggunaan gadget, maka anak akan tumbuh dan berkembang sesuai dengan harapan.

\section{SARAN}

Berdasarkan kesimpulan tersebut maka diharapkan orangtua bijak dalam memberikan gadget terhadap anak karena mengingat dampak negatif yang akan terjadi. Orangtua juga harus konsisten dalam mendisiplinkan anak menggunakan gadget, hal tersebut juga berkaitan dengan orangtua harus mampu menjadi contoh yang baik bagi anak. Pendidikan agama sangat dibutuhkan dalam upaya menghindarkan anak dengan gadget. Selain itu, orangtua juga diharapkan memfasilitasi anak dengan permainan edukatif yang bertujuan agar anak dapat bermain bersama teman sehingga anak mengenal lingkungan sekitarnya.

\section{DAFTAR PUSTAKA:}

Ameliola, S. \&. (2013). Perkembangan Media Informasi dan Teknologi terhadap Anak dalam Era Globalisasi. Prosiding The 5 th International Conference on Indonesian Studies "Ethnicity and Globalization". .

American Academy of Pediatrics Committe on Public Education. (2011). Children, Adolescents, and television Pediatr, 423-426.

Imron, R. (2017). Hubungan Penggunaan Gadget dengan Perkembangan Sosial dan Emosional Anak Prasekolah di Kabupaten Lampung Selatan. Junal Keperawatan, 13(2), 148-154.

Kartono, K. (1980). Pengantar Metodologi Reasearch Sosial . Bandung: Alumni.

Maulida, H. (2013). Menelisik Pengaruh Penggunaan Gadget Terhadap Perkembangan Psikologis Anak Usia Dini . Semarang: FKIP Universitas Negeri Semarang.

Mesman, d. (2013). The Impact of Technology Dependence on Children and Their Families. Journal of Pediatric Health Care Volume 27, 6.

Mayar, F. (2013). Perkembangan Sosial Anak Usia Dini sebagai Bibit Unggul Masa Depan Bangsa. Jurnal Al-Ta"lim, Jilid I. Fakultas Ilmu Pendidikan Universitas Negeri Padang.

Nurrachmawati. (2014). Pengaruh Sistem Operasi Mobile Android Pada Anak Usia Dini. Jurnal Penagruh Sistem Operasi Mobile Android Pada Anak Usia Dini.

Novitasari, W. (2016). Dampak Penggunaan Gadget Terhadap Interaksi Sosial Anak Usia 5-6 tahun. Surabaya: UNS.

Soetjiningsih, C. (2012). Perkembangan Anak. Jakarta: Prenada. 
Santrock, J. W. (2007). Perkembangan Anak. Jakarta: Erlangga.

Sundus, M. (2018). The Impact of using Gadgets on Children . Journal of Depression and Anxiety, 1-3.

Santrock, J. (2002). Perkembangan Masa Hidup Edisi ke-5 Jilid 1. Jakarta: Erlangga.

Sugiman, W. \&. (2016, Desember 26). Diambil kembali dari http://stmikglobal.ac.id/wpcontent/uplo ads/2014/05/ARTIKELIS.

Yenny, Y. (2017). Gambaran Perkembangan Motorik Anak Usia 5-6 tahun yang Bermsin Games Gadget. Peran Psikologis Perkembangan dan Pertumbuhan Humanitas pada Era Digital . Prosiding Temu Ilmiah X Ikatan Psikologi Perkembangan Indonesia.
Semarang: Ikatan Psikologi Perkembangan Indonesia.

Vitrianingsih, Khadijah, S. \& Ceria, I. (2018). Hubungan peran orangtua dan durasi gadget dengan perkembangan anak pra sekolah di TK gugus ix Kecamatan Depok Sleman Yogyakarta, Jurnal Formil, 3 (2), 101-109. Doi: 10.3584/formil.v3i2.178

Zed, Mestika, 2008. Metode Penelitian kepustakaan, Jakarta: Yayasan Obor Indoesia. 